\title{
DID (AND DOES) THE IRISH BORDER MATTER?
}

Cormac Ó Gráda and Brendan M Walsh 


\title{
DID (AND DOES) THE IRISH BORDER MATTER?
}

\section{Cormac Ó Gráda and Brendan M Walsh}

\author{
Working Papers in British-Irish Studies \\ No. 60,2006 \\ (also printed as \\ MFPP working paper no. 10)
}

Institute for British-Irish Studies

University College Dublin 


\section{IBIS Working Papers \\ No. 60,2006 \\ (also printed as \\ MFPP working paper no. 10)}

(C) the authors, 2006

ISSN 1649-0304 


\section{ABSTRACT}

\section{DID (AND DOES) THE IRISH BORDER MATTER?}

This paper examines how the two parts of Ireland were affected by the partition of the country in 1922. It examines the post-partition evolution of living standards north and south, and patterns of trade, migration, and road and rail traffic between the two since 1922. A separate section looks at the effects of living near the border on population trends. Bearing in mind the difficulty of establishing a relevant counterfactual-what would have happened in the absence of partition-we conclude that while it is possible to discern a "partition effect", it is smaller and less significant than is widely perceived. The evidence we present is a salutary warning against great expectations about the possible economic gains from the dismantling the barriers erected between the two parts of Ireland after 1922.

\section{Publication information}

Revised version of a paper presented at final conference of the Mapping frontiers, plotting pathways: routes to North-South cooperation in a divided island programme, City Hotel, Armagh, 19-20 January 2006.

The programme is funded by the Special EU Programmes Body through the Higher Education Authority over the period 2004-06.

\section{Acknowledgements}

We thank Harry McGeehan (CIÉ, Dublin), Derek Brady (National Roads Authority, Dublin), and Jonathan Alexander (Census Office for Northern Ireland, Belfast) for data, and Andrew McGuinness for research assistance. Thanks also to Patrick McWilliams, Eoin Magennis, John Nolan, Kieran Rankin, and Tom Ferris for help on various points. We are also grateful to John Coakley, Brendan O'Leary, Colm McCarthy, and participants at the Mapping frontiers, plotting pathways conference in Armagh, January 2006, for helpful comments. 


\section{BIOGRAPHICAL INFORMATION}

Cormac Ó Gráda is a professor in the School of Economics, UCD. He is the author of Ireland: a new economic history (Oxford University Press, 1994), Black '47 and beyond (Princeton University Press, 1999), Jewish Ireland in the age of Joyce: a socio-economic history (Princeton University Press, 2006), Ireland's great famine: interdisciplinary essays (UCD Press, 2006), and many journal publications in economic and demographic history. He is a member of the Royal Irish Academy.

Brendan M Walsh is emeritus professor of economics at UCD, where he was Professor of National Economics, 1980-2005. He is the co-author of After the Celtic tiger (O'Brien Press, 2002) and The macroeconomy of the eurozone (Gill and Macmillan, 2003). He is also the author or co-author of many journal articles in macroeconomics, demography, and economic history. He is a member of the Royal Irish Academy and an Honorary Fellow of the Society of Actuaries in Ireland. 



\section{DID (AND DOES) THE IRISH BORDER MATTER? Cormac Ó Gráda and Brendan M Walsh}

\section{INTRODUCTION}

At the end of my 500 kilometres, I have crossed the border 35 times, never having been more than $8 \mathrm{~km}$ away from the borderline. But I have not met a single border policeman, soldier or customs officer, let alone paramilitaries. ${ }^{1}$

Political borders need not influence the level or the structure of economic activity, but they usually do. Borders, or the communal or political tensions that give rise to them, are likely to reduce the flows of goods and of people below what they would be in their absence. Some borders are more destructive in this sense than others, however.

The economic costs of borders such as that between the Republic and Northern Ireland can be considered in several different ways, depending on the counterfactual believed to be relevant. One approach might be to consider how much did (or does) a particular border reduce trade below what it would be in a borderless entity. The economic costs of the Irish border in this sense are presumably much less today, in a context of the European Union and the free movement of goods and persons between the two Irelands, than they were during the protectionist era between the early 1930s and 1960s. In this context Norman Gibson's remarks of nearly half a century ago seem apposite:

It is sometimes said that partition has added to Ireland's problems. If this is true then it is primarily because of our own stupidity and our refusal to co-operate on common economic problems (Gibson, 1959: 9).

Nonetheless differences in fiscal, monetary, and currency regimes remain. Car triptychs and swingeing customs duties may be things of the past, but there are still forms to be filled and queues to be endured (but compare Logue, 1999: 89-91, 11213, 36-38). Significant excise tax differentials in particular persist, affecting especially cars, petrol and other fuels, alcoholic beverages, and some other consumer goods. Moreover, the Republic's entry to the exchange rate mechanism of the European Monetary System in March 1979 introduced a flexible exchange rate between the two parts of Ireland for the first time ${ }^{2}$ and this change was consolidated by the adoption of the euro south, but not north, of the border.

\footnotetext{
1 Friedhelm Rathjen, German travel writer, 1999. Available www.shortall.info/Touring/border.htm [2005-0818].

${ }^{2}$ Not quite: while Bank of Ireland notes depreciated relative to English banknotes in the wake of the suspension of gold payments in 1797, the value of northern banknotes rose relative to those of the Bank of Ireland (see Fetter, 1955). Curiously, the effect of the more recent (1979) change was not discussed in the white paper issued prior to the Republic's decision to join even if sterling did not. According to Joe O'Toole, Marketing
} 
A second approach is to inquire how the north-south border has affected the flow of people and goods between the two jurisdictions. It would not be surprising to find, for example, that the "troubles" disrupted the day-to-day movements of goods and people across the Irish border, particularly between the early 1970s and mid-1990s, but on the other hand they provoked some longer-term movement by those fleeing to more congenial environments.

The topic can also be explored at various levels and in various ways. At its broadest, we could include questions about the uses to which the Republic put its newfound economic and political freedom, comparing its performance as an independent state with what it might have been had it remained part of the United Kingdom. We touch only briefly on this question, regarding it as too challenging to be properly covered in this essay. For the most part our focus is narrower, namely on whether the border and the "troubles" can be said to have markedly disrupted trade and settlement patterns. Methodologically, both cross-sectional and time series data are relevant. The first allow us to make some north-south comparisons that address the question "Is the flow (of trade or people) between the two areas smaller (or different) than would be expected if, for example, they were two parts of the same economy?" But we must bear in mind that an affirmative answer to this question could be due to long-standing structural factors that are hard to impound in ceteris paribus. ${ }^{3}$ Time series that look at pre- and post-partition flows would seem to offer a surer way of assessing the impact of the border. However, we have relatively few data that allow such comparisons. In the following section, however, we have ranged far and wide to draw together evidence of both types to shed light on the impact of partition.

Casual observation and individual case studies suggest that the border impedes or distorts economic activity in various ways. In 1936 an article in the Round Table (cited in Johnson, 1974: 52) claimed that over 60,000 cattle had been smuggled into Northern Ireland from the south during the previous year, while half a century later research by Desmond Norton showed how the EU Common Agricultural Policy led to massive two-way smuggling in livestock and agricultural products such as butter across the Irish border (Norton, 1986). John FitzGerald and his colleagues at the $\mathrm{ESRI}$ documented in some detail the effect of excise tax discrepancies and exchange rate fluctuations on cross-border imports of alcohol and tobacco (FitzGerald et al., 1988). ${ }^{4}$ Less formally, the Irish News recently highlighted the case of the

Manager at Craigavon-based Moy Park, Ltd. "the constantly fluctuating sterling-euro relationship tends to have an impact on the amount of [North-South] trade. Tight margins mean that a 1-2\% movement in the currency rate may wipe out a company's profits". More generally, claims O'Toole, "It is easier at the moment to trade in the Eurozone and this is perhaps the reason behind the decreasing trade on the island" (see http://tradestatistics.intertradeireland.com/cms/publish/article_21.shtml). However, econometric analysis has failed to establish that the change of currency regime adversely affected the volume of trade between the Republic and the UK (Thom and Walsh, 2002).

3 The Canada-US example comes to mind. Geography as well as politics probably helps account for the much greater east-west than north-south flows.

4 Paradoxically, this consequence of the border increased trade in both directions-Irish whiskey exported to the North, where it was subject to relatively low excise duties, was imported back to the South by cost- 
southern-based sales representative of a Derry entrepreneur who had her northernregistered company car impounded by customs officers in County Meath. ${ }^{5}$ Equally curious is the absence of a petrol station on the main Dublin-Belfast route between Drumcondra in Dublin city and immediately north of the border. For years prior to the construction of the Drogheda bypass, the last station south of the border on the main road was in Drogheda, about 25 miles to the south! It is likely that partition also influenced the character and size of property transfers, both of land and housing, near the border, although it would take close study at the micro level to establish this. Another interesting issue that would benefit from a "micro" analysis is the success or otherwise of businessmen and enterprises seeking to benefit from the border. Again, a close study of the history of the railway network in border areas (north Leinster and south Ulster) might reveal that partition reduced the survival prospects of lines in those areas $^{6}$ although their longer-term prospects were in any event poor.

The structure of this paper is as follows. Part 2 briefly considers the evolution of living standards north and south of the border after partition. Part 3 concentrates on merchandise trade. It begins by documenting how Northern Ireland's share of the south's merchandise trade has evolved since the 1920s. It then focuses more formally on whether the border has artificially reduced trade between the two jurisdictions, using data on cross-border trade between other pairs of economies as a benchmark. Parts 4 and 5 offer some evidence on trends in the size and character of north-south and south-north migration. Part 6 analyses some relevant road and rail traffic, both historical and contemporary. Part 7 discusses the economic costs (or otherwise) of being located next the border. Part 8 reviews and concludes our study.

\section{THE TREND IN LIVING STANDARDS}

Drawing on the widely-cited international comparisons of GDP per person compiled by Angus Maddison (2001), we obtained the picture of the south's living standards measured in GDP per person in constant (Geary-Khamis dollars) shown in figure 1.

The data for the war years should be treated with caution, ${ }^{7}$ but clearly there was some deterioration in the south's relative position during the 1930 s and no improvement until the 1960s. Following renewed setbacks in the first half of the 1980s, the catch-up was all the more rapid and dramatic in the 1990s. Perhaps surprisingly, it was carried over in the current decade, bringing the Republic into the premier league as far as this measure of living standards is concerned. ${ }^{8}$ Just as the

conscious shoppers who arrived in Newry by the bus load, bringing to mind of smuggler's motto: "Divided we stand, united we fall"!

5 “Entrepreneur detoured by Republic's road rules", Irish News, 20 July 2005.

${ }^{6}$ Thus partition accelerated the closure of the Castleblaney-Armagh line. We are grateful to Kieran Rankin for this information.

7 The figure for the Republic is suspiciously constant over the years 1938-46!

8 It is widely accepted that GDP is a misleading indicator of Irish living standards. GNP is to be preferred. But even though GNP now falls some $20 \%$ short of GDP, it remains true that Ireland is now among the world 


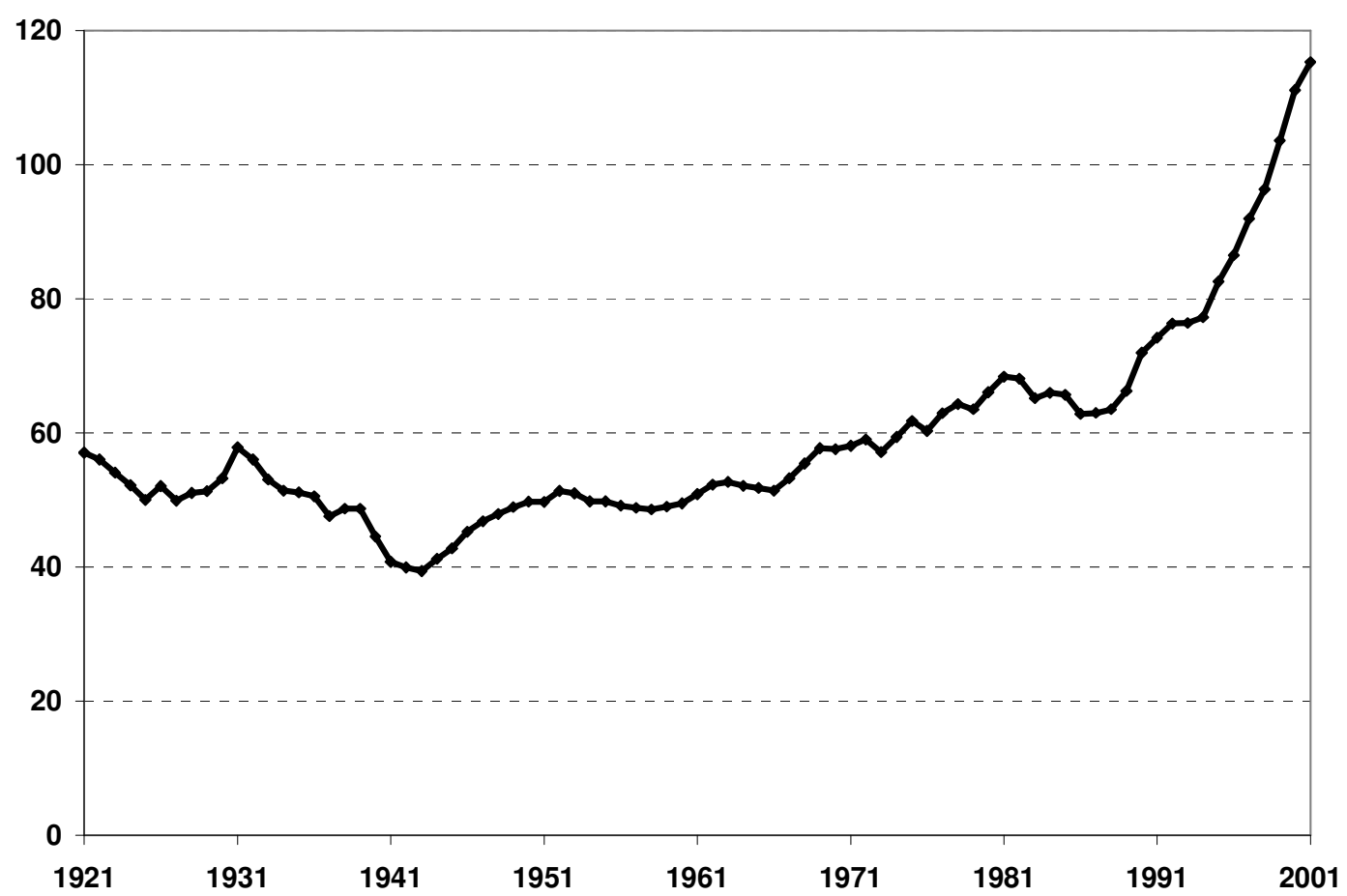

Figure 1. Real per capita income, Republic of Ireland, as percentage of that of UK, 1921-2001

Note: based on 1990 international Geary-Khamis dollars

weak economic performance over the decades of 1930s, 1940s, 1950s, and again in the first half of the 1980s, should be attributed to mistakes in economic policy that might have been avoided had Ireland been part of the wider UK, it is valid to attribute much of the country's exceptional performance since the end of the 1980s to domestic policy initiatives that would not have been possible without economic independence. Chief among these is the use of fiscal autonomy to lure foreign capital to the country through low corporation tax rates and other incentives, but mention should also be made of relatively high spending on education and an emphasis on post-primary courses that appear to deliver a supply of labour that is attractive to "sun rise" industries and internationally traded services.

By contrast, the Northern Ireland experience as part of the UK has been marked by very slow convergence towards the UK average, in terms of both productivity and personal income per capita (figure 2). The relatively poor economic performance of the Northern Ireland economy in recent decades is partly due to the decline of the industries in which it so heavily specialised, namely linen and shipbuilding. It is also plausibly linked to the "troubles", which may help explain both the disproportionate role of public sector employment and the increasing gap between income and productivity (see Crafts, 1995). 


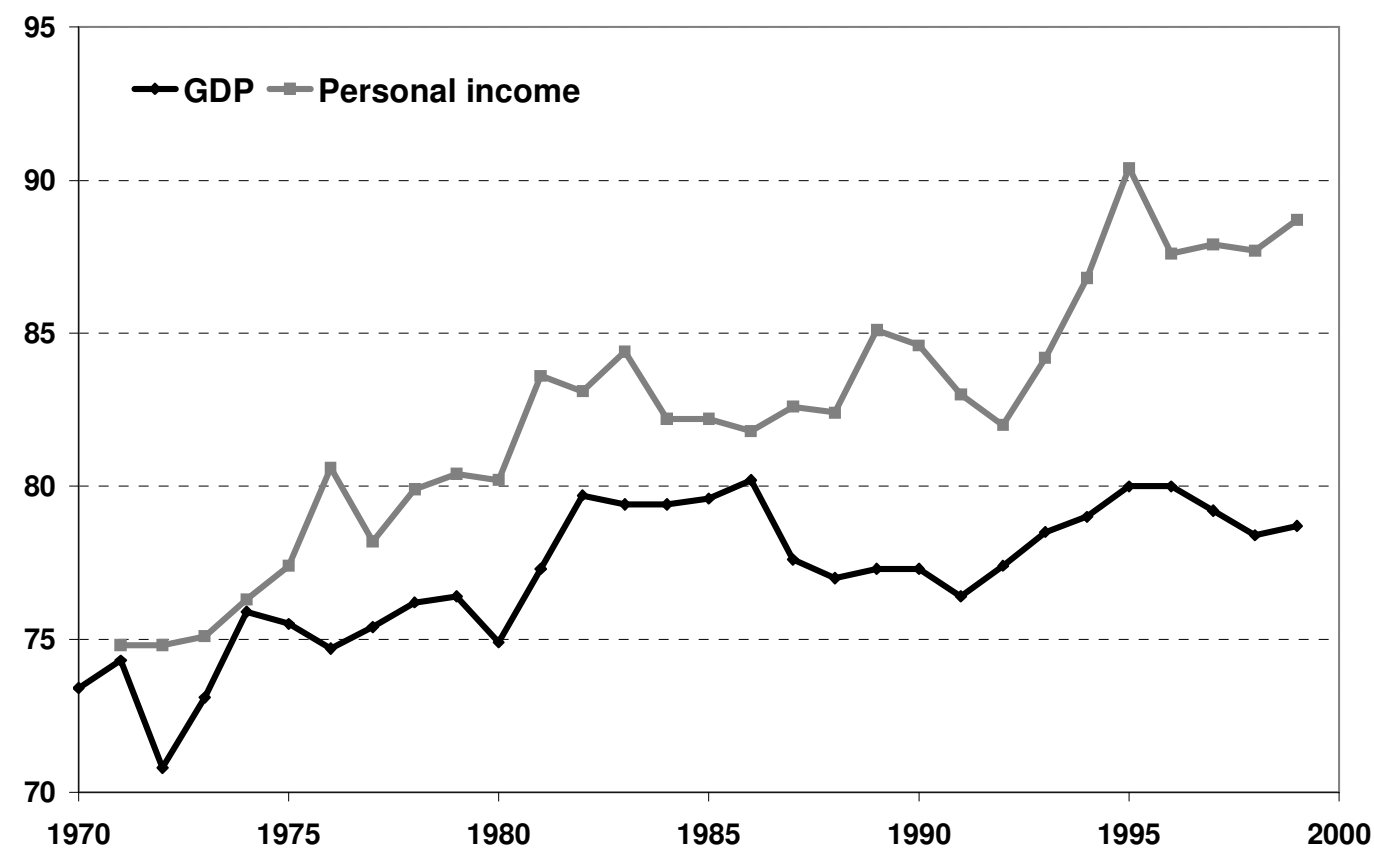

Figure 2. Real per capita GDP and personal income, Northern Ireland, as percentage of that of UK, 1970-99

\section{MERCHANDISE TRADE}

The Free State was quick to exercise its new autonomy in the area of trade policy. By the mid-1930s a thorough system of protectionism had been established and of course it applied to north-south trade, which had previously been completely free of tariffs, quotas, and other artificial impediments. As a result of this, and of course the downward spiral in world trade during the great depression, the country's total trade volumes fell. For us, however, the key question is whether the impact on northsouth trade was greater than on the south's trade with other areas. In assessing this issue, we should bear in mind that the pre-partition structure of the two economies was based on east-west rather than north-south flows. The north was markedly specialised in export industries such as linen, shipbuilding, engineering, tobacco and rope making, which neither bought many of their inputs nor sold many of their outputs to the south, while the main exports from the south were livestock and other agricultural produce, with beer and whiskey predominating among the meagre industrial exports. In exchange for these, the south imported consumer goods and capital equipment, mainly from Britain. The purpose of the protectionist walls erected by the south in the 1930s was to foster import substituting industrialisation, creating employment by replacing imports of consumer goods with domestically produced products. We would not expect this form of protectionism to have had a dramatic impact on north-south trade-if anything a greater impact on the volume and composition of trade with Britain would be expected.

Figures 3 and 4 describe Northern Ireland's trade with the Republic as a proportion of all Republic of Ireland trade and as a proportion of Republic of Ireland-Great Brit- 
ain trade. These data first become available in 1924 so they do not allow a pre/postpartition analysis. The import series was subject to a definitional change in 1937. Until then the trade statistics categorized imports by where they were "consigned from" rather than by their "origin". The fact that significant quantities of imports were first imported to the United Kingdom before being shipped to Ireland meant that the recorded share of the UK (including Northern Ireland) in total imports was much higher before than after 1936. In order to allow for this effect, we have assumed that that imports from Northern Ireland were a constant share of all Republic of Ireland imports until 1936.

It bears noting that for centuries exports to Great Britain have formed a higher proportion of total Irish exports than imports from Great Britain have formed of total Irish imports. Similarly, from the outset Northern Ireland has been more important in proportionate terms as a destination for Republic of Ireland merchandise exports than as a source of Republic of Ireland imports. In other words, the Republic has consistently run a balance of trade surplus with both parts of the UK. Considered as a percentage of total Republic of Ireland exports, recorded exports to Northern Ireland fell during the 1920s and 1930s. Hardly surprisingly, they rose significantly during the second world war and for a few years in its wake. Then they fell from a peak of $18.4 \%$ in $1943-47$ and $12.5 \%$ in the late 1960 s to their very low level of $1.7 \%$ today. Although we cannot say that this was due to partition, figure 3 implies that the relative decline in Northern Ireland as a market for Republic of Ireland exports preceded the renewed outbreak of the "troubles" in the 1970s by several decades; nor does evidence from the post-1970 period show much sign of a "peace dividend" in this sense. Figure 3 indicates that until recent years Northern Ireland's share of total Republic of Ireland imports held its own, but it was much smaller than Northern Ireland's share of the Republic's exports until recent decades. However, figure 4 shows that when Northern Ireland-Republic of Ireland trade is considered in the context of Republic of Ireland-Great Britain trade, the long-run decline in Northern Ireland's share of Republic of Ireland trade has not been so striking-indeed, it reflects the decline in Northern Ireland's share of the UK's trade. The Northern Ireland share in all UK-Republic of Ireland trade is even now still much greater than the Northern Ireland share of UK GDP or population (see below). This was particularly so in the case of Republic of Ireland exports. Nonetheless, figure 4 also implies that relative to Great Britain, Northern Ireland's share of the Republic's trade fluctuated without clear trend until the early 1970s, when the export share began to decline considerably, with a decline in the import share evident only in the past decade. In sum, as the Republic's economy grew at historically unprecedented rates from the late 1980 s on, the northern economy loomed smaller in its trading links.

It is likely that the secular trends reflect several factors: (a) the decline of the Northern Ireland and British economies relative to those of Europe and North America; (b) the geographical diversification of foreign trade that typically follows the break-up of political units; and (c) Irish membership of the EU and the pro-foreign direct investment regime pursued by the Republic of Ireland since the 1960s, which may have diverted some Republic of Ireland exports away from traditional markets but much more importantly resulted in a dramatic increase in the Republic's imports of raw materials from the USA and exports to the USA and Europe. Significantly, 


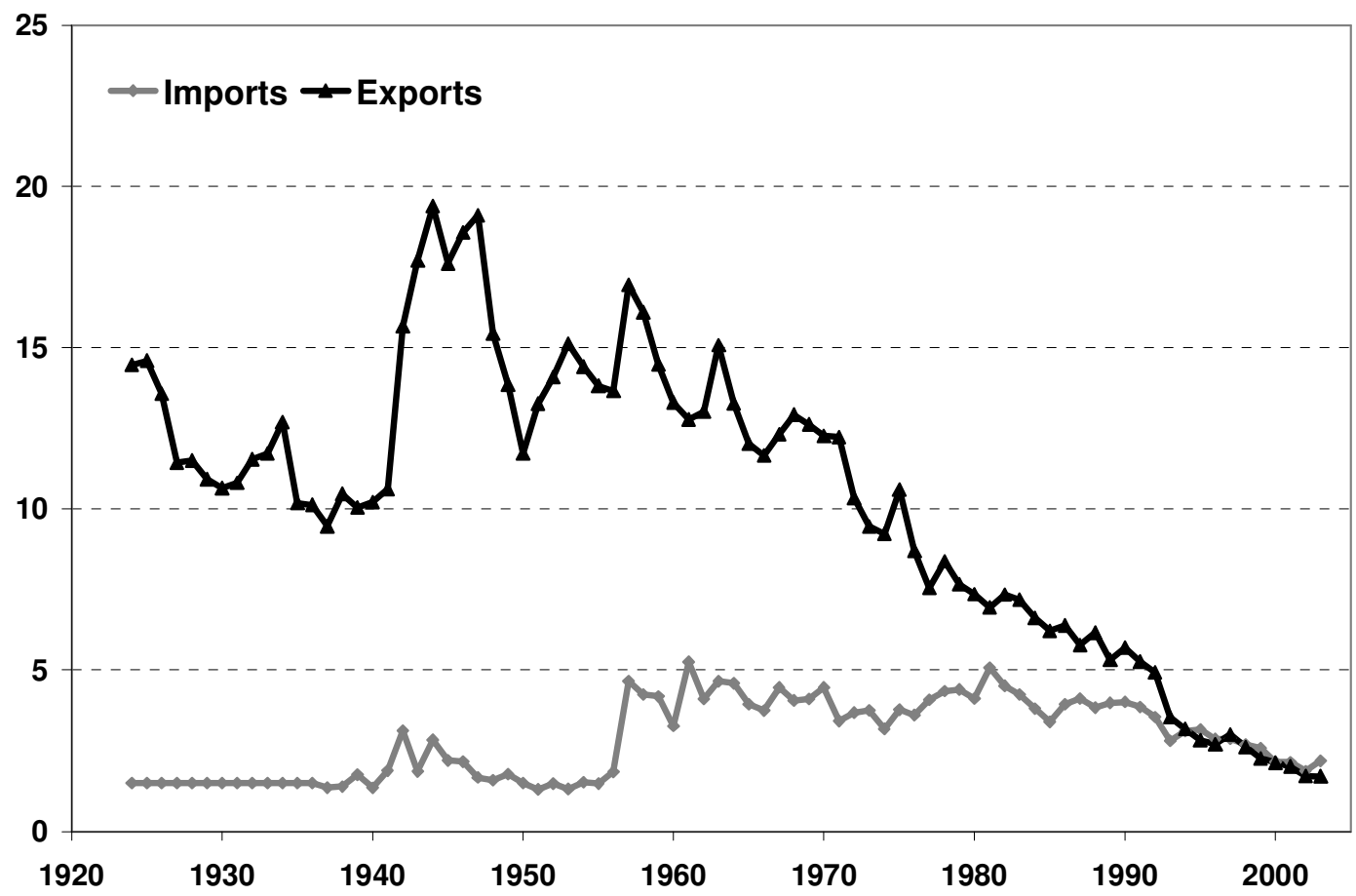

Figure 3. Trade with Northern Ireland as percentage of all Republic of Ireland trade, 1924-2003

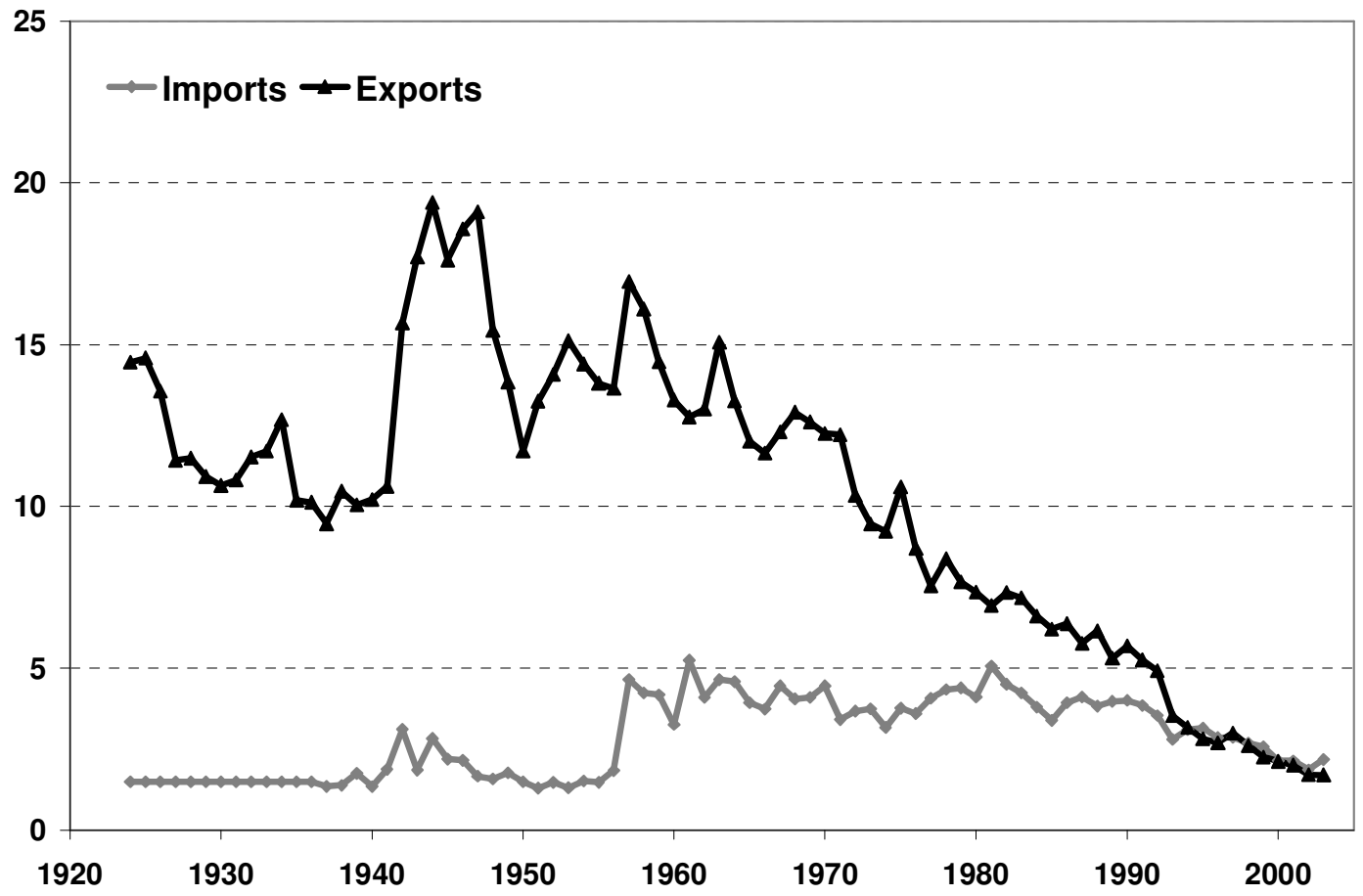

Figure 4. Republic of Ireland trade with Northern Ireland as percentage of Republic of Ireland trade with Great Britain, 1924-2003 
movements in Northern Ireland output per head in recent years have been much closer to those of the rest of the UK rather of the Republic.

The sense that the border has hindered merchandise trade between the Republic and Northern Ireland is widespread, but the issue has not been subjected to formal testing until recently. A recent econometric study (Fitzsimons et al, 1999) compares the volume of trade between the two Irelands with that between each of them and other parts of the world. In order to determine whether north-south flows are less than expected, they apply a standard gravity model widely used in the trade literature. This model posits that the size of trade flows between economies is positively related to the size of their GDPs per capita and their populations, and negatively related to the distance between them, allowing for the influence of other relevant factors. The authors conclude that north-south trade is actually greater than would be expected on the basis of a model that takes account of the standard determinants of trade flows. ${ }^{9}$

We have no quarrel with this finding. As Fitzsimons et al (1999) point out (and, indeed, as shown by figure 4), crude comparisons strongly suggest that the volume of trade between the two parts of Ireland is relatively large. In 1998 the Republic's trade with Northern Ireland amounted to more than $10 \%$ of its trade with the United Kingdom (including Northern Ireland), whereas Northern Ireland accounted for less than $3 \%$ of the UK's population and only about $2 \%$ of its GDP. It would be surprising if the impression conveyed by these simple comparisons were reversed by econometric analysis.

The aim of the study by Fitzsimons et al (1999) was to go beyond casual empiricism and explore whether actual north-south trade volumes are high or low by reference to what would be expected on the basis of a gravity model that controls for the influences of income, population, distance, land borders, and common languages on trade flows. The model is estimated on a data set consisting of a panel of observations on bilateral trade in manufactured goods (SITC 4-9) ${ }^{10}$ between 28 developed countries for the years 1970-92. It is found that the actual volume of north-south trade significantly exceeds the level "predicted" by the gravity model and the impression conveyed by a crude examination of the data is confirmed. This conclusion is of interest because for 14 of the 23 years in the sample the exchange rate between the two economies was floating. Although the issue is not discussed, the study offers no grounds for believing that breaking the sterling link reduced the volume of north-south trade. ${ }^{11}$

\footnotetext{
9 Smyth (1995: 175) cites an earlier study by Scott and O'Reilly (1992) which finds that "the level of crossborder trade is in line with that experienced between other small European countries and their nearest neighbours".

${ }^{10}$ For more on the Standard International Trade Classification (SITC), see http://www.intracen.org/ tradstat /sitc3list.htm

${ }^{11}$ Compare Simpson (1995: 94): "Of all the economic variables, an unstable North South exchange rate relationship would be a deterrent to further economic integration."
} 
While much more sophisticated than conclusions based on casual empiricism, we should be aware that the study by Fitzsimons et al (1999) does not formally address the impact of partition on trade flows, containing no pre/post-partition comparison. It could be, for example, that although the level of north-south flows are higher than predicted by the standard model, they would have been even higher had the island not been economically divided in 1922 .

Our overall conclusion is that the evidence does not support the widely-held view that the existence of the border (or an exchange rate) has resulted in an abnormally low level of trade flows between the two parts of Ireland. This is hardly a case of "back-to-back" economies; in fact there is real evidence that at various stages excise tax and currency fluctuations stimulated two-way trade flows. However, we acknowledge that the lack of before/after data limits our ability to pinpoint the effect of partition with greater certainty.

\section{MIGRATION AND RESIDENCE}

Endemic high rates of unemployment and emigration in the south implied that most of the movement from the north to the south in the earlier decades of partition was more a flow of refugees or asylum seekers rather than of economically motivated migrants. We would expect that partition had a greater impact on movement from the south to the north. By the 1930s the Northern Ireland Parliament had moved to restrict freedom of employment and settlement in the province by Free State citizens. This was a response to fears that the relative prosperity of the northern economy would attract a substantial inflow of migrants from the south and upset the nationalist-unionist demographic balance in the province. In any event, the job opportunities generated in the north by the war-time economy did not induce a large inflow from the south, as may be seen from travel permits records. ${ }^{12}$ The permits issued were overwhelmingly for travel to Great Britain, with Northern Ireland accounting for a mere $1.5 \%$ of the 115,231 permits issued between 1943 and 1946.13

In their 1970 study of migration between the two Irelands Roy Geary and Gerry Hughes found that in 1961 the border acted as a deterrent to migration from the Republic to Northern Ireland and that it affected Roman Catholic migrants more than migrants of other denominations. But Geary and Hughes believed that "this phenomenon of lower and, as we think, diminishing association, has lasted for hundreds of years" (1970a: 44), rather than being a pattern that emerged with partition. They found that the expected number of Republic of Ireland residents in Northern Ireland was considerably less than that predicted by migration patterns within the south. However, their "onerous" calculations (1970a: 40) made no allowance for history or for economic factors other than distance.

\footnotetext{
12 Between 1939 and 1947 travel permit cards were required for persons of 16 years of age and over entering Great Britain or Northern Ireland. For a discussion of this arrangement see Commission on Emigration and other Population Problems 1948-1954, paragraph 273 and appendix VI.

13 lbid., statistical appendix table 30-figures for Northern Ireland are not available for the years 1947-51.
} 


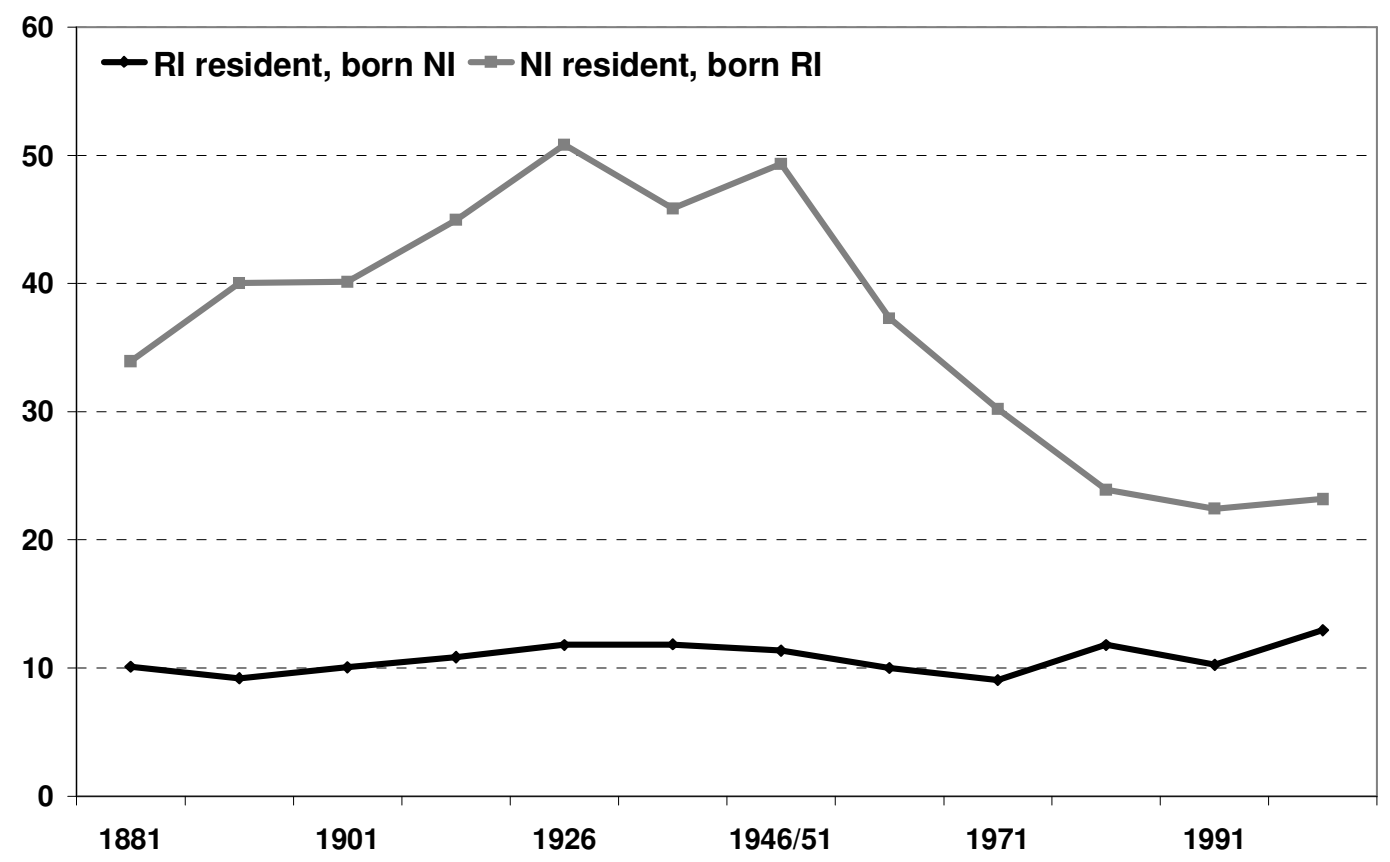

Figure 5. Republic of Ireland and Northern Ireland residents born in the other jurisdiction, 1881-2001/02 (per thousand)

Figure 5 extends the chronological coverage offered by Geary and Hughes, and report the numbers born in one part of Ireland and resident in the other over the period between 1881 and 2001-02. The comparison prompts the following observations:

1. Despite fluctuations, the Northern Ireland-born population resident in the south is not dramatically different now than it was in the 1880s (relative to the south's population), especially in the case of men.

2. On the other hand, there has been a pronounced secular decline in the proportion of Northern Ireland population that was born in the south, especially noticeable between 1951 and 1981 .

3. In the early 1960s there were almost twice as many southerners living in the north as vice versa. When account is taken of the populations of the two jurisdictions, southerners were four times as likely to reside in the north as vice versa. This was mainly a reflection of pre-1930s movements. Perhaps it was fears of invasion from the south that provoked the passage of the Safeguarding of Employment Act (1947) that restricted the capacity of persons born outside the UK movement to take up employment in Northern Ireland. ${ }^{14}$ However, by 1981 there were more Northern Ireland-born residents of the south than there were southern residents of Northern Ireland, and by 2002 the latter outnum-

\footnotetext{
14 Under the 1947 Act persons who were not "Northern Ireland workers" within the meaning of the Act are not entitled to enter employment in Northern Ireland unless a permit was issued to them to do so by the Ministry of Health and Social Services. This measure was not repealed until 1981.
} 
bered the former by $28 \%$. Some of this presumably reflected the significant flow of refugees to the south as the "troubles" reached a climax in the early 1970s.

4. Women were in the majority for almost the whole period among migrants in both directions, but this was especially so for northward migration. The enduring "femaleness" of the Republic-Northern Ireland migration is striking. In 2001, 55.7\% of Republic of Ireland-born workers in Northern Ireland were female, as compared to less than $40 \%$ of British born, and $45 \%$ of those born elsewhere outside Northern Ireland. This might suggest a propensity for southern women to marry northern men.

5. There was a post-partition effect. The number of Northern Ireland residents born in the south rose significantly between 1911 and 1926, but began to decline thereafter. The numbers do not bear out Geary and Hughes's assertion that "there was little sign of change in migration behaviour occasioned by the Treaty" (1970a: 48).

6. That northerners constituted a declining proportion of the southern population from 1936 to 1971 is probably attributable to the underperformance of the southern economy over these years. The big rise in the number of Northern Ireland-born in the south between 1971 and 1981 is probably linked to the "troubles". These later "troubles" caused a bigger movement southwards than the "troubles" of the post-1920 period did northwards.

7. The "Celtic tiger" provoked considerable movement from north to south. Northern Ireland-born residents of the south are probably now more numerous than at any time in the past. But the increase in the proportion of the Republic's population born in the north-from $9.8 \%$ in 1991 to $12.7 \%$ in 2001 for males-is not as great as might be expected given the dramatic increase in immigration to the Republic from more distant jurisdictions over this period. Recently released figures show that "non-Irish nationals" accounted for almost exactly $50 \%$ of the increase in employment in the south in 2005, of whom only $15 \%$ were from the UK (including Northern Ireland). Moreover, in the 2002 census, only $4.6 \%$ of the usual residents of the Republic who had been living elsewhere one year previously were from Northern Ireland. Only $4.9 \%$ of those born outside the Republic who moved in over the year were born in Northern Ireland-a total of only 2,482.

8. The huge increase since the 1970s in the numbers of people born in one Republic of Ireland county and resident in another Republic of Ireland county was not matched by increases in cross-border movements. However, the increase in the numbers of Northern Ireland-born resident in the Republic in the 1990s is due mainly to the same underlying economic causes.

We now look at developments in some border counties in more detail. Figure 6 describes the numbers of persons born in the six counties of Northern Ireland, and resident in five southern border counties (Louth, Donegal, Monaghan, Cavan and Leitrim) between 1881 and 2002, as a proportion of county population. Almost throughout the period, the proportions were highest in Monaghan and lowest in Lei- 


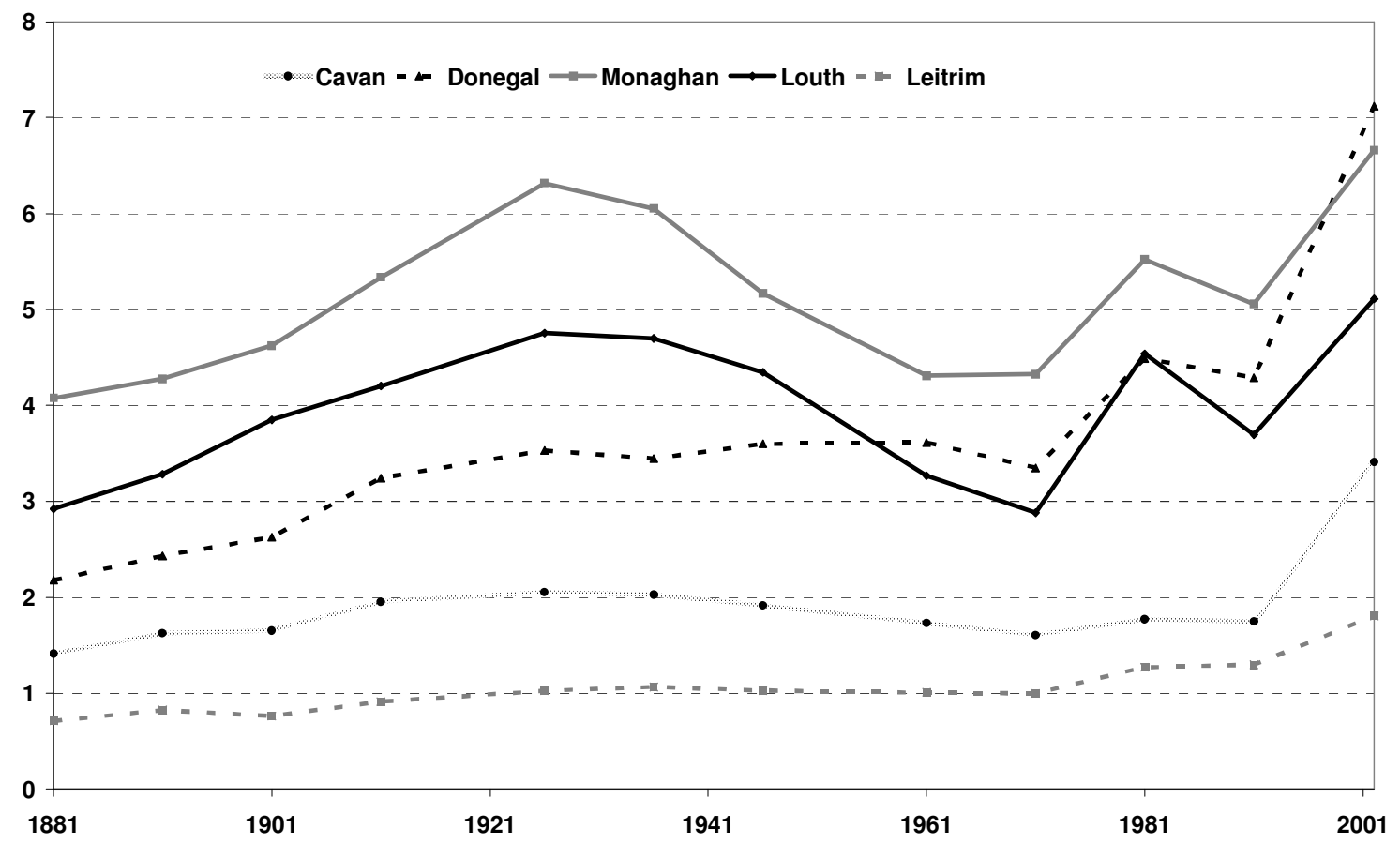

Figure 6. Northern Ireland-born residents of border counties of the Republic, 1881-2002 (per cent)

trim. The association between a county's length of border and proportion Northern Ireland-born is loose. It fits Leitrim, but neither Donegal nor Louth.

There are signs of a "border effect" south of the border for counties Monaghan and Louth in 1926, but in the case of the other three counties it is not discernable. Thereafter the proportions born in Northern Ireland declined in both counties until 1971, when sectarian tensions prompted a considerable number of northerners to move south. In all five counties the proportions born in the north dropped between 1981 and 1991, but then rose to an all-time high in 2002. This is presumably a reflection of the relative affluence of the post-"Celtic tiger" southern economy.

Figure $7 \mathrm{a}$ refers to people born in Cavan, and living in the neighbouring counties of Meath-Monaghan and in Northern Ireland in census years between 1881 and 2002. They suggest that partition mattered, to the extent that while the Meath-Monaghan ratio rose almost throughout, the Northern Ireland ratio fell as a percentage between the 1930s and the 1970s. The picture for Monaghan-born residents born in the contiguous counties of Cavan Louth and in Northern Ireland (figure 7b) is very similar.

The demographic history of a comparable county on the other side of the border tells a similar story. Before partition, Fermanagh residents born elsewhere in Ireland were much more likely to have been born in what would become the Republic than in the future Northern Ireland. By 1981 the opposite was true, and during the 1980s the numbers of Fermanagh residents born elsewhere in $\mathrm{NI}$ increased dramatically, while numbers born in the South barely held their own. 


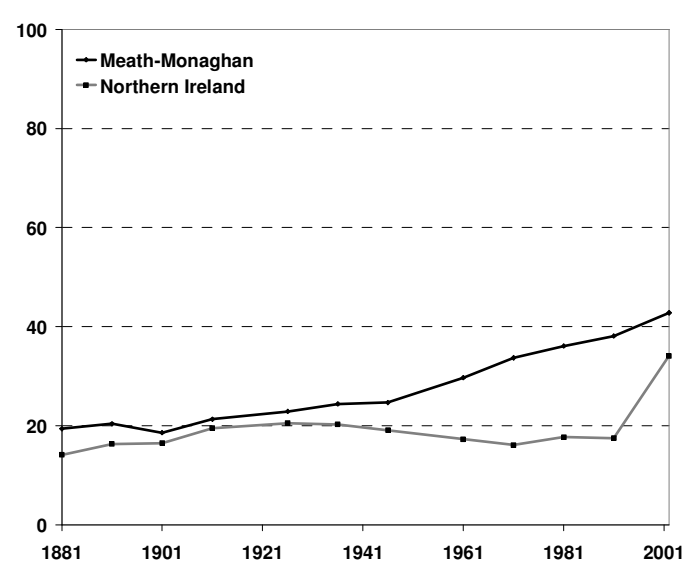

(a) Cavan

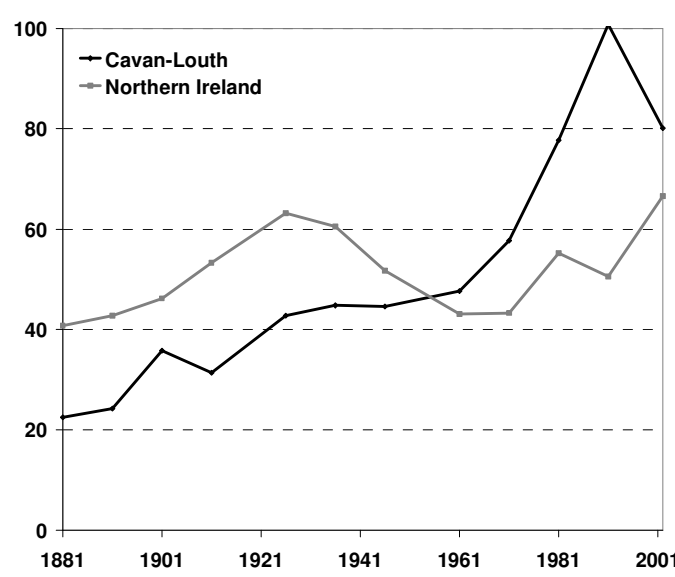

(b) Monaghan

Figure 7. Residents of Cavan and Monaghan born in selected adjacent counties and in Northern Ireland, 1881-2002 (per thousand)

So far we have been relying on place-of-birth data in the census, which refer to the cumulative stock of migrants over many years. Since 1981 the Republic's census also provides data on residence one year earlier, which offers a sense of the flowor the emigration rate-in the previous year. These data are described in table 1.

Table 1. Destinations of Northern Ireland migrants to Republic of Ireland, 1981-2002

\begin{tabular}{lrrrrr}
\hline Region & 1981 & 1986 & 1991 & 1996 & 2002 \\
\hline Border & 732 & 439 & 551 & 661 & 1,668 \\
& $(28.5)$ & $(37.0)$ & $(37.0)$ & $(29.8)$ & $(47.8)$ \\
Dublin & 1,059 & 404 & 490 & 997 & 948 \\
& $(41.2)$ & $(34.0)$ & $(32.9)$ & $(44.9)$ & $(27.1)$ \\
Mid-East & 157 & 118 & 118 & 143 & 204 \\
& $(6.1)$ & $(9.9)$ & $(7.9)$ & $(6.4)$ & $(5.8)$ \\
South-West & 156 & 51 & 71 & 91 & 144 \\
& $(6.1)$ & $(4.3)$ & $(4.8)$ & $(4.1)$ & $(4.1)$ \\
Mid-West and South-East & 263 & 99 & 148 & 145 & 201 \\
& $(10.2)$ & $(8.3)$ & $(9.9)$ & $(6.5)$ & $(5.8)$ \\
West & 108 & 48 & 59 & 138 & 243 \\
& $(4.2)$ & $(4.0)$ & $(4.0)$ & $(6.2)$ & $(7.0)$ \\
Midlands & 95 & 29 & 53 & 44 & 83 \\
& $(3.7)$ & $(2.4)$ & $(3.6)$ & $(2.0)$ & $(2.4)$ \\
Total & 2,570 & 1,188 & 1,490 & 2,219 & 3,491 \\
& $(100.0)$ & $(100.0)$ & $(100.0)$ & $(100.0)$ & $(100.0)$ \\
Rate per 1,000 population & 1.7 & 0.7 & 0.9 & 1.3 & 2.1 \\
& & & & & \\
\hline
\end{tabular}


The numbers are small in absolute terms. The total in $1981(2,570)$ was probably inflated by the "troubles". 15 The inflow in 1980-81 $(1,188)$ was much smaller, but it has been rising steadily since then. The number was higher in 2002 than in any previous census year, as was the rate per thousand of the Northern Ireland population. If maintained the 2002 rate ( 2.1 per thousand) would represent a significant fraction of the current natural rate of population increase in Northern Ireland.

Table 1 describes the numbers and shares of those resident in Northern Ireland a year previously by planning region. ${ }^{16}$ It shows that Dublin and the border counties accounted for the lion's share ( $70 \%$ or more) of the migration in this period. Dublin's share has been falling and that of the border counties rising, although in this respect 1996 is an outlier. It is significant that the share of the border counties-traditionally considered an underdeveloped part of the south—peaked at $47.8 \%$ in 2002.

In 1990-91 the movement from the Republic to Northern Ireland matched that from Northern Ireland to the Republic; the 1991 Northern Ireland census recorded 1,458 residents (661 males and 797 females) who had been living in the south a year previously. Over one-third of these were living in either Belfast or Derry. In 2000-01, the number of southern migrants moving north-2,329 (1,046 males and 1,273 females) - was also higher than a decade earlier. Its age-structure implies a migration driven by economic factors: $76 \%$ of the males and $79 \%$ of the females were aged between 15 and 44 years. About half of these migrants had been born in Northern Ireland: a census cross-tabulation of "country of address one year ago by country of birth" reveals 1,119 persons born and resident in the Republic a year previously. ${ }^{17}$

\section{MIGRATION AND SKILL STATUS}

From 1926 to 1991 the southern census contains useful information on the occupations of immigrants from Northern Ireland. In 1926 the southern labour force contained 13,361 Northern Ireland-born males and 5,077 Northern Ireland-born females. By 1961 the numbers had fallen to 9,003 males and 3,189 females-barely $1 \%$ of the total labour force. ${ }^{18}$ As already noted, it is not clear whether this decline reflected the poor performance of the southern economy or should be attributed in part at least to partition.

Table 2 compares the representation of Northern Ireland-born workers in the main occupational groups in 1926 and 1961. The "other producers" category includes manufacturing, construction, mining, and fishing.

\footnotetext{
15 Presumably some of the refugees eventually returned to the North.

16 The Midwest and Southeast regions have been combined, since only county-level data on previous residence are available for Tipperary, the two parts of which are allocated to separate planning regions.

17 http://www.nisra.gov.uk/census/Excel/commissioned_output/EXT20040628A.xls

18 A probably minor issue is that the population is by place of residence but the labour force and occupations could be cross-border-consider a Northern Ireland-born person living in Dundalk working in Newry!
} 
Table 2. Distribution of Northern Ireland-born workers in main occupational groups relative to Republic of Ireland-born workers in Republic of Ireland, 1926 and 1961

\begin{tabular}{lrrrr}
\hline Occupational group & $\begin{array}{l}1926 \\
\text { Males }\end{array}$ & Females & $\begin{array}{l}1961 \\
\text { Males }\end{array}$ & Females \\
\hline Agriculture & & & & \\
Other producers & 30.9 & 28.9 & 32.8 & 50.5 \\
Transport & 113.4 & 113.9 & 82.7 & 45.9 \\
Clerks, typists & 118.3 & 149.9 & 88.5 & 28.8 \\
Commerce & 343.9 & 201.2 & 218.6 & 125.2 \\
Services & 253.6 & 110.1 & 185.8 & 95.5 \\
Public administration & 150.2 & 113.5 & 159.8 & 84.7 \\
Professions & 450.9 & 299.3 & 471.7 & 440.5 \\
Others gainfully occupied & 456.9 & 244.6 & 391.6 & 220.7 \\
& 99.6 & 112.5 & 214.2 & 85.6 \\
Total & & & 100.0 & 100.0 \\
\hline
\end{tabular}

Note: Republic of Ireland-born $=100$

Source: derived from Geary and Hughes, 1970a

This suggests that these were considerably over-represented in public administration and in the professions in both years, and under-represented in agricultural occupations. Clerks and typists were also over-represented among Northern Irelandborn workers in both 1926 and 1961. Between the two dates, however, the Northern Ireland representation in "other producer" occupations fell considerably. ${ }^{19}$ In sum, the data suggest that north-south migration was disproportionately one of whitecollar office and professional workers. Table 3 repeats the exercise for 1961, 1981, and 1991. The comparison suggests a relative "de-skilling" of immigrants in the wake of the outbreak of the "troubles". Making the comparison for 2002, after the "Celtic tiger", would be of particular interest, but the 2002 census does not provide the relevant cross-tabulation.

Migration northwards from the Republic has also contained a disproportionate share of white-collar and skilled labour. In 2001 the Northern Ireland population included 11,590 males and 19,094 females born in the south; $63.6 \%$ of the males and $53.1 \%$ of the females were economically active; of the economically active, $9.2 \%$ of the males and $5.9 \%$ of the females were unemployed. The economically active born in the Republic were disproportionately skilled and white-collar, a larger proportion than Northern Ireland residents born in Great Britain (see table 4). ${ }^{20}$

\footnotetext{
${ }^{19}$ The sources for the underlying data are: 1926 census, Vol. III, pp. 194-95; Geary and Hughes 1970b: 48 (citing 1961 census, Vol. VII (Part 2), tables 9A and 9B).

20 Derived from data downloaded on August 22nd 2005 at http://www.nisra.gov.uk/census/Census 2001Output/commissioned_output.html; Table EXT20032908D (Sex and Economic Activity by Country of Birth); Table EXT20032908 H (Sex and Occupation by Country of Birth of Employed Persons). An entry greater than one in table 4 implies the overrepresentation of Irish- or GB-born workers in the relevant occupational category.
} 
Table 3. Distribution of Northern Ireland-born workers in occupational sectors relative to Republic of Ireland-born workers in Republic of Ireland, 1961-1991

\begin{tabular}{lrrrrrr}
\hline Sector & 1961 & & 1981 & & 1991 & \\
& Males & Females & Males & Females & Males & Females \\
\hline Agriculture & 33 & 50 & 33 & 49 & 39 & 54 \\
Mining & 32 &. & 21 &. & 47 &. \\
Electrical & 168 &. & 97 & 74 & 93 & 51 \\
Engineering & 125 &. & 101 &. & 91 & 49 \\
Wood & 101 &. & 113 &. & 100 & 55 \\
Leather & 103 & 58 & 49 & 59 & 114 & 100 \\
Textiles & 103 & 57 & 77 & 60 & 84 & 91 \\
Food, beverages, tobacco & 60 & 15 & 50 & 51 & 61 & 61 \\
Paper & 109 & 34 & 53 & 41 & 59 & 37 \\
Other products & 81 &. & 64 & 62 & 70 & 50 \\
Building and construction & 70 &. & 181 &. & 164 &. \\
Painters and decorators & 97 &. & 123 &. & 129 & 127 \\
Crane Operators etc & 77 &. & 75 &. & 60 &. \\
Foremen & 113 &. & 115 & 86 & 93 & 89 \\
Transport and comm.. workers & 88 & 50 & 68 & 33 & 75 & 56 \\
Warehouse workers etc. & 94 & 23 & 58 & 51 & 70 & 56 \\
Clerical & 218 & 125 & 87 & 82 & 100 & 78 \\
Commerce and insurance & 186 & 95 & 140 & 87 & 106 & 84 \\
Service & 184 & 84 & 106 & 97 & 102 & 89 \\
Labour unskilled & 42 & 30 & 61 & 61 & 66 & 60 \\
Administrative & 470 & 420 & 225 & 165 & 198 & 160 \\
Professional and technical & 392 & 221 & 241 & 172 & 216 & 169 \\
Armed forces & 215 &. & 109 &. & 97 &. \\
Other & 124 & 97 & 94 & 92 & 81 & 80 \\
Labour force & 100 & 100 & 100 & 100 & 100 & 100 \\
\hline Note: Republi & & & & & &
\end{tabular}

Note: Republic of Ireland-born $=100$

Source: derived from Census of Ireland, 1961-1991

Table 4. Occupational distribution of Republic of Ireland-born and British-born residents of Northern Ireland, 2001

\begin{tabular}{lcccc}
\hline Occupational group & \multicolumn{2}{c}{ Republic of Ireland } & \multicolumn{2}{c}{ Great Britain } \\
& Male & Female & Male & Female \\
\hline 1. Managers and senior officials & 1.26 & 1.12 & 1.16 & 1.17 \\
2. Professional & 1.83 & 1.45 & 1.05 & 1.15 \\
3. Associate professional/technical & 1.04 & 1.53 & 2.38 & 1.31 \\
4. Administrative and secretarial & 0.72 & 0.72 & 1.12 & 0.84 \\
5. Skilled trades & 0.78 & 1.13 & 0.52 & 0.80 \\
6. Personal service & 1.04 & 0.90 & 1.02 & 0.97 \\
7. Sales and customer service & 0.86 & 0.72 & 0.64 & 0.85 \\
8. Process, plant and machine operatives & 0.88 & 0.65 & 0.76 & 0.90 \\
9. Elementary occupations & 0.81 & 0.93 & 0.79 & 0.98 \\
\hline
\end{tabular}

Note: Figures refer to representation of Irish- and GB-born residents relative to NI population as a whole. 


\section{MERCHANDISE TRAFFIC VOLUMES}

Given that Dublin and Belfast are easily the two biggest cities on the island, traffic between them might be expected to account for a considerable share of all-Ireland passenger transport. This is not so, at least insofar as railroad traffic is concerned. Figure 8, based on data from the state transport company CIE, clearly shows the impact of the "troubles" on north-south traffic. From the early 1970s the BelfastDublin line was subject to repeated disruptions from events ranging from a concerted IRA bombing campaign, civil disturbances, various engineering works, strikes, and an outbreak of foot-and-mouth disease that led to restrictions on travel. Despite all this, passenger traffic is higher now than it was before the "troubles". Yet as figure 9 shows, it continues to be a small fraction of total rail passenger traffic in the Republic. Figure 10 illustrates clearly the resilience of north-south traffic in the context of the "troubles", whose initially disruptive effect appears to have been overcome relatively quickly. It implies that the recovery on the Dublin-Belfast line in the 1990s has been only partly in response to the IRA ceasefire: Belfast traffic has risen only modestly relative to traffic on the island's other main double-track route, that between Cork and Dublin. ${ }^{21}$

A further perspective on north-south flows is offered by traffic counter data collected by the National Roads Authority (NRA). ${ }^{22}$ Figure 11 describes traffic flows as measured on a selection of routes between 1985 and 2004, figure 11a referring to routes that lead to the border, figure $11 \mathrm{~b}$ to routes within the south. Traffic grew in both categories: on the five southern routes by an average of $179 \%$ over the period, on the border routes by $169 \%$. The difference is small. However, table 5 , which describes levels rather than growth rates, confirms the relative unimportance of northsouth traffic, when compared to south-south traffic. It nevertheless remains a challenge to explain whether this is due to partition or to some deeper structural factors.

In sum, despite the ceasefire and improvements in the quality of the road network and much talk of a Belfast-Dublin economic corridor, in the 2000s both road and rail traffic remains modest relative to that on southern routes. No doubt more could be done (to promote this traffic?), but these findings surely temper optimism about for the potential benefits of public expenditure on such an economic corridor. Several years ago geographer Jim Walsh pointed out that the statistical evidence in the consultancy report, contrary to the rhetoric of the project, suggested that "the two cities have business sectors that have been developed independently so that there are very few complementarities and there is no tradition of inter-city linkages" (Walsh, 1995: 62).

\footnotetext{
21 Jim Walsh (1995: 62) cites corroborative data on intercity telephone traffic in the early 1990s. The traffic between Dublin and Belfast was only two-fifths that between Dublin and Cork, although Cork's population was only about one-third of Belfast.

22 Data for 1997-2004 are available at www.nra.ie/Transportation/TrafficDataCollection/Traffic CounterData/. Derek Brady, NRA, provided data for earlier years. We have interpolated for a few missing observations.
} 


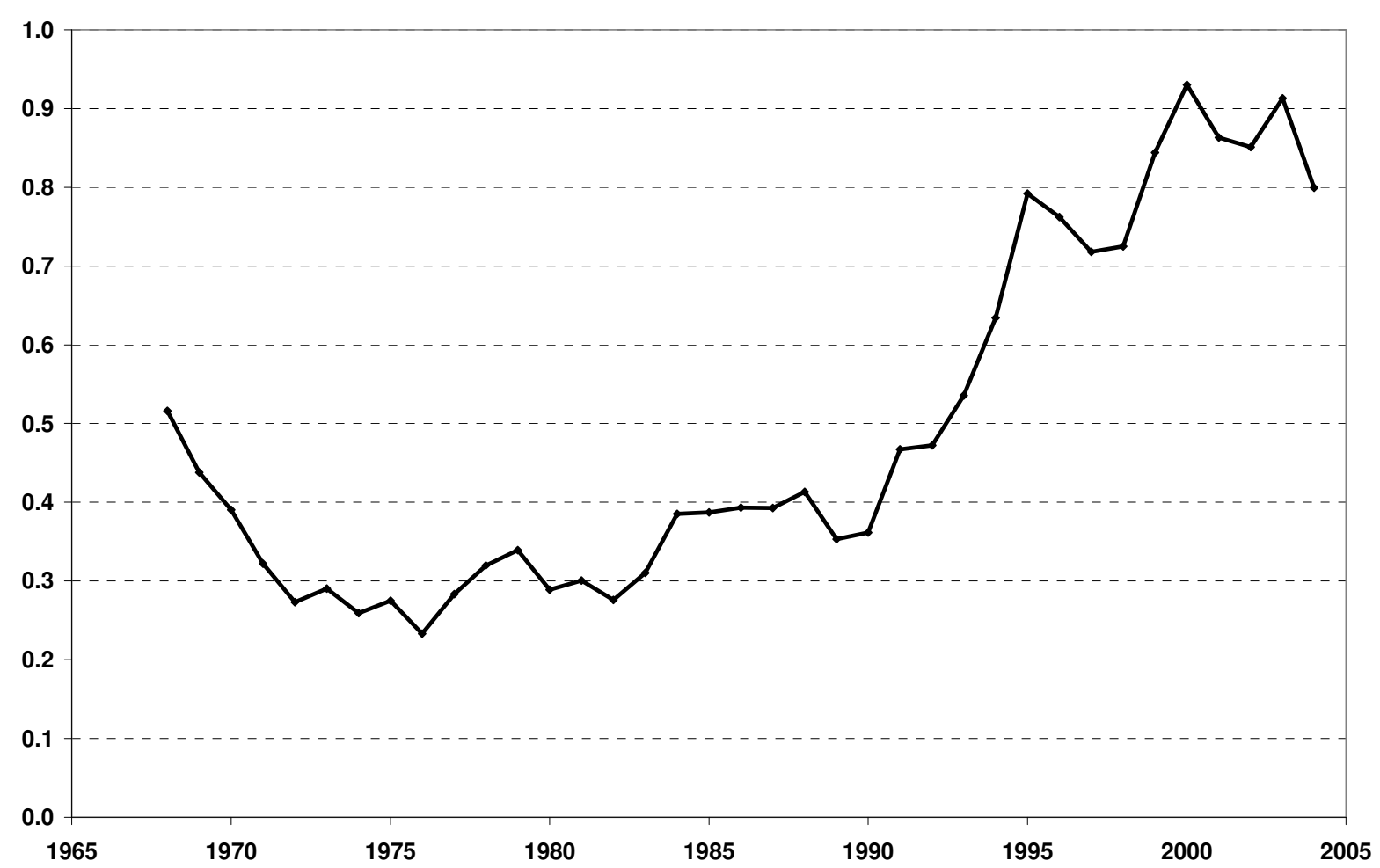

Figure 8. Passengers on the Dublin-Belfast railway line, 1968-2004 (millions)

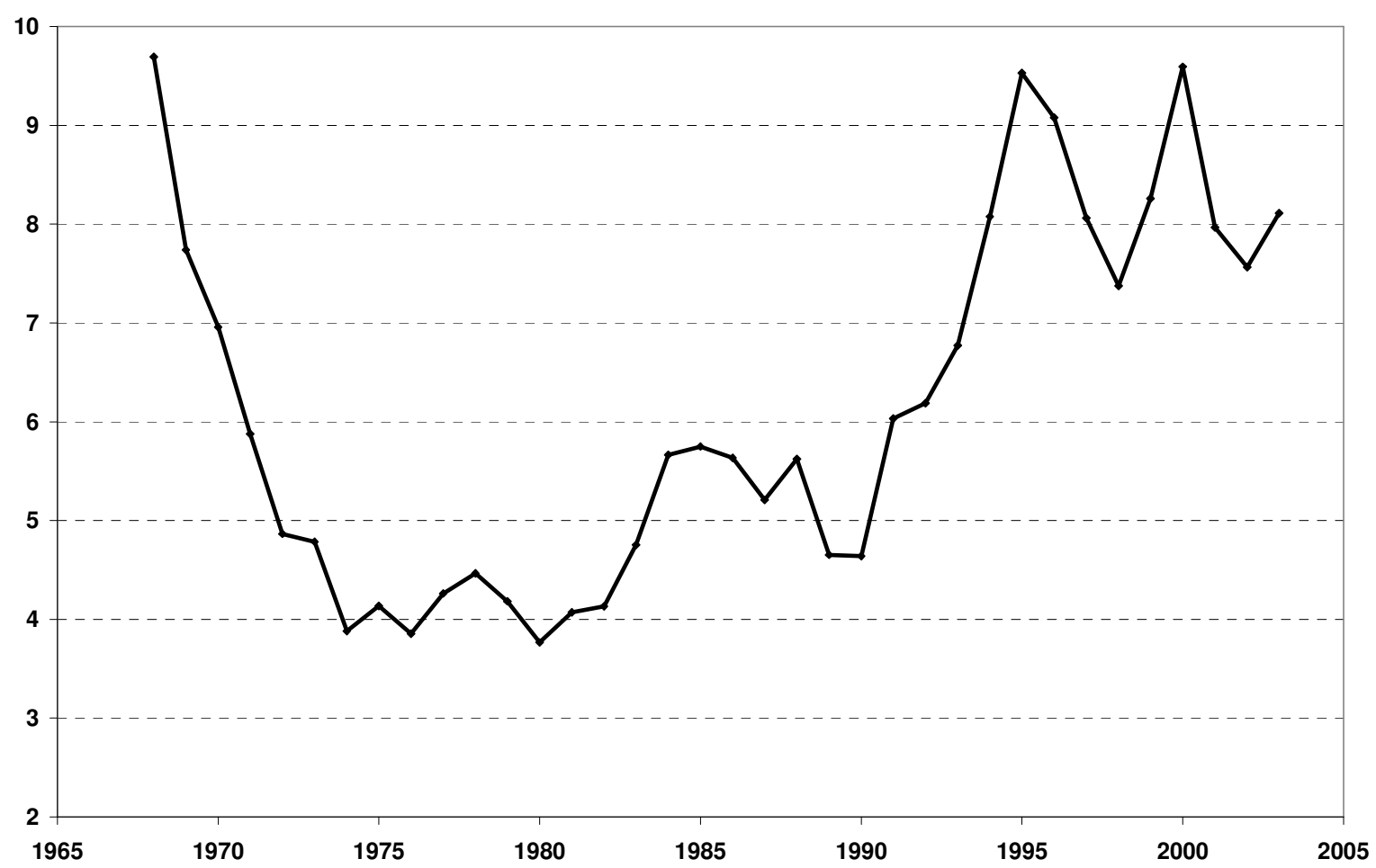

Figure 9. Cross-border passengers as percentage of all rail passengers, 1968-2003 


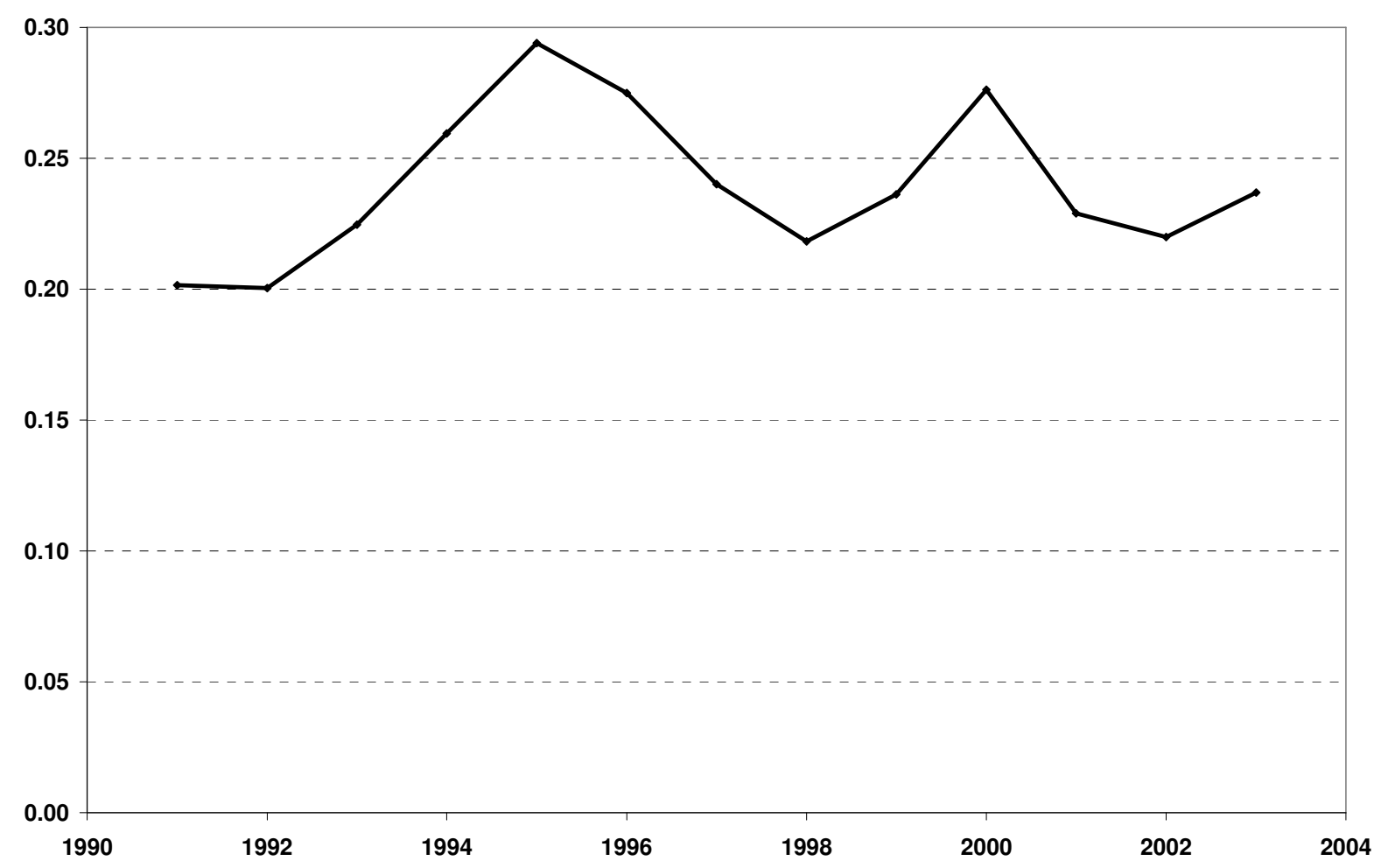

Figure 10. Belfast-Dublin rail traffic as proportion of Cork-Dublin rail traffic, 1991-2003

Table 5. Traffic counter data, 2004

\begin{tabular}{lcc}
\hline Location & Road & Traffic Counted \\
\hline South & & \\
Monasterevin & $\mathrm{N} 7$ & 24,487 \\
Junction with N59 (Mayo) & $\mathrm{N} 8$ & 15,163 \\
Kill & $\mathrm{N} 7$ & 61,559 \\
Leaving Fermoy & $\mathrm{N} 7$ & 12,588 \\
Gorey Northwards & $\mathrm{N} 11$ & 14,325 \\
Roundabout N17 & $\mathrm{N} 6$ & 25,879 \\
Limerick-Kerry boundary & $\mathrm{N} 21$ & 13,367 \\
North & $\mathrm{N} 1$ & \\
Border & $\mathrm{N} 2$ & 18,877 \\
Border at Moybridge & $\mathrm{N} 2$ & 5,265 \\
Border at Aghalane & $\mathrm{N} 12$ & 2,630 \\
Border near Glaslough & $\mathrm{N} 13$ & 5,406 \\
Bridgend & $\mathrm{N} 16$ & 12,295 \\
Border at Belcoo & & 2,757 \\
& & \\
\hline
\end{tabular}




\section{THE LOCAL IMPACT OF THE BORDER}

Borders probably have a particular impact on those living near them. A recent study of the impact of the division and reunification of Germany on towns located near the border found that such towns lost population relative to other towns. The losses could not be attributed to differences in industrial structure or wartime destruction: the problem was the loss of market access. Moreover, those towns that lost out prior to 1989-90 have tended to recover since then (Redding and Sturm, 2005).

The impact of the border on living standards in the Irish border counties remains unclear. In claiming that household expenditure data in the south "[do] not indicate any overall deterioration in the border region's relative position", a 1995 report commissioned by the Forum for Peace and Reconciliation in fact understates the progress made in the border counties since the 1970s (Forum for Peace and Reconciliation 1995: 164). Indeed, estimates of disposable income show that between 1973 and 1994 average disposable income in Donegal and the northeast rose from $75.6 \%$ of the national average to $92.5 \%$, and that in 2002 disposal income per head in the border counties was about $90 \%$ of the national average. ${ }^{23}$ Curiously, perhaps, the latest Central Statistics Office (CSO) data imply at best no convergence towards the national average during the past decade of relative peace.

Nonetheless, it is often claimed that the border stunted the growth of counties (on both sides) that had their economic hinterland disputed after 1922 by tariffs, policing, and the separate development of the north and the south. It is said-and plausibly so-that partition deprived some towns on both sides of the border of some of their natural trading hinterland (for example, New Ireland Forum, 1984, para. 6.7). Critics of partition highlighted the problem from the start. Newry and Derry are obvious examples, ${ }^{24}$ but for two decades after 1971 much of counties Cavan and Leitrim was virtually cut off from the other side of the border due to the destruction of bridges and roads at scores of "unapproved" border crossings. A Leitrim County Council delegation complained to the Border Regional Authority of "once self-reliant towns and villages [which] had become little more than ghost towns" (cited in Forum for Peace and Reconciliation, 1995: 165; see too Robb, 1995; Curtis, 1994). In Cavan, it was claimed that towns like Swanlinbar and Belturbet were similarly affected. On the other hand, people and places next to the border were sometimes in a position to benefit from their location: the border village of Jonesboro, just off the main Dublin-Belfast road on its Northern Ireland side, flourished economically in the 1980s, while petrol station proprietors south of the border were later able to profit

\footnotetext{
23 The 1973 and 1994 data are derived from Boyle, McCarthy and Walsh 1999. For later data see http://www.cso.ie/releasespublications/documents/economy/current/regincome.pdf (downloaded 8 August 2005).

24 Derry nationalists claimed that "the economic life of the city was largely dependent on its connection with Tirconaill", while the Boundary Commission argued that "to sever Newry from Northern Ireland would be to separate it from the country to which in an economic sense it belongs, and to expose it to economic disaster" (Hand 1969: 80, 135).
} 
from a big north-south price differential. ${ }^{25}$ On balance, has location on or near the border been an advantage or disadvantage in economic terms?

Here we take a preliminary look at this issue from two vantage points. The first compares the growth of border and non-border counties in the south. The most salient indicator of an economic impact would be a loss of population-relative to the totals that might otherwise have been recorded-in border counties. The obvious difficulty in assessing this lies in obtaining a plausible estimate of how the population would have developed. We propose a very simple model that "predicts" the rate of county population growth after 1911 simply in terms of the growth rate over the period 1841-1911. It is reasonable to obtain our counterfactual in this way in as much as invariant geographical influences (such as climate, location and the distribution of ports) and initial conditions (such as the level of urbanisation in 1841) seem to account for the broad pattern of population development in the south after 1841 (Walsh, 2000). The key question then becomes this: did the border counties fare worse than predicted after 1911 (the date of the last pre-partition census)?

We obtained the following results from applying the very simple regression model summarised in table 6 . Ag41 refers to the proportion of the population mainly occupied in agricultural pursuits. Border is a dummy variable equal to 1 for the five counties with a border with Northern Ireland, and 0 otherwise.

Table 6. Estimating the impact of the border on county population change

\begin{tabular}{lrrrrr}
\hline & \% change & \% change & \% change & \% change & \% change \\
& $1911-61$ & $1911-61$ & $1911-96$ & $1841-1996$ & $1961-81$ \\
\hline Constant & 0.47 & 0.51 & 0.44 & 10.47 & -1.871 \\
& $(5.52)$ & $(6.82)$ & $(2.21)$ & $(3.45)$ & $(-0.30)$ \\
Ag41 & & & & -0.267 & 0.121 \\
& & & & $(-3.30)$ & $(0.73)$ \\
Ag41Sq & & & & 0.002 & -0.001 \\
& & & & $(2.98)$ & $(-0.94)$ \\
Border & -0.053 & -0.128 & -0.292 & -0.143 & 0.201 \\
& $(-0.88)$ & $(-1.94)$ & $(-1.65)$ & $(-2.67)$ & $(-1.84)$ \\
PopCh41-11 & 0.872 & 0.740 & 1.431 & 0.998 & -0.104 \\
& $(5.27)$ & $(5.03)$ & $(3.62)$ & $(2.76)$ & $(-0.14)$ \\
$N$ & 32 & 26 & 26 & 26 & 26 \\
$\mathrm{R}^{2}$ & 0.50 & 0.57 & 0.42 & 0.964 & 0.510 \\
$\mathrm{~F}(4,21)$ & & & & 140.22 & 5.45 \\
& & & & $(.000)$ & $(.000)$ \\
\hline
\end{tabular}

Note: t-statistics in brackets. The two 1911-61 columns refer to (1) all Ireland and to (2) Republic only.

\footnotetext{
${ }^{25}$ Captured, for example, in the whimsy of Peter Ormrod's film Eat the Peach (1986) and in Desmond Norton's study of livestock smuggling induced by the EU's common agricultural policy in the 1980s (summarized in Norton 1986).
} 
Results based on 32 and 26 counties are given for 1911-61; the remaining regressions refer to the 26 counties only. The equations highlight the role of the "path dependence" of population growth at the county level-rates of change over the 70 years before 1911 are indeed significantly related to rates of change in the subsequent fifty and eighty-five year periods, although as might be expected the fit of the model deteriorates over the longer period.

The performance of Border is suggestive of a negative effect. Although not highly significant, the implication is that ceteris paribus border counties grew less rapidly after 1911 than would have been expected on the basis of their historical record. In the first two equations the coefficient suggests that partition reduced the population of the border counties by some $13 \%$ over the period $1911-1961$ and $29 \%$ over the period 1911-1996 (the annual average impact is slightly greater over the longer period, but the level of statistical significance is lower.) The share of the five border counties in the total population of the Republic was $14.6 \%$ in 1911, so if the border effect captured in our results represent a net loss of population to the Republic it would represent just $4.2 \%$ of the 1996 total.

Second, we look at the impact of location on the prosperity of urban locations, great and small, by comparing the population growth of towns located on or next to the border with that of towns some distance from it. The exercise is based on a database of over forty urban locations, ranging in size from hamlets like Pettigo, Kesh, and Dowra to major centres like Newry, Derry, and Sligo. ${ }^{26}$ We sought to model town population change as follows:

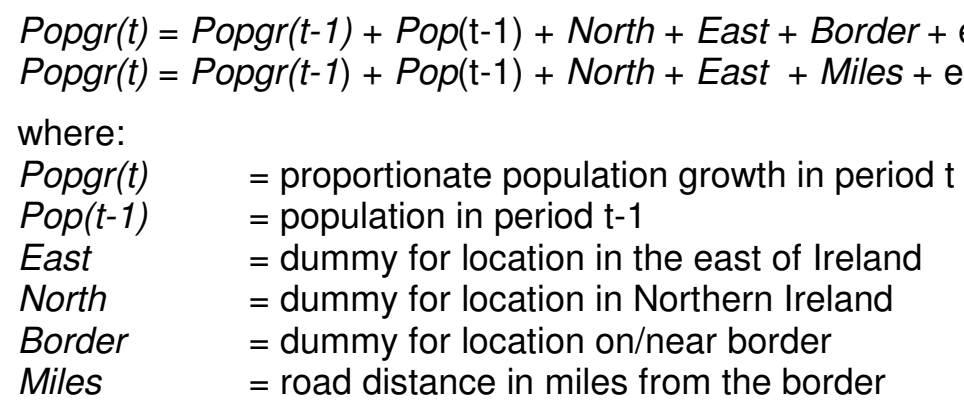

The lagged term Popgr(t-1) represents an attempt to control for path-dependence, i.e. the possibility that population growth or decline persisted from one period to the next, while Pop allows for the possibility of path dependence over time. North is a crude attempt to capture differences in the dynamism of the two economies, and East is a proxy for location in the less remote part of the island.

\footnotetext{
26 The towns included are (assumed miles from the border in parentheses): Banbridge (16), Coleraine (34), Omagh (19), Limavady (21), Newcastle (28), Irvinestown (9), Newtownstewart (8), Kesh (4), Dromore (15), Newry (3), Strabane (0.5), Derry (4), Aughnacloy (0), Castlederg 93), Cavan (12), Cootehill (10), Ballybofey/Stranorlar (14), Carrickmacross (6), Dowra (8), Belturbet (3), Bailieborough (16), Buncrana (8), Glenties (25), Raphoe (6), Castleblayney (4), Ballybay (10), Newbliss (5), Letterkenny (17), Ballyshannon (3), Clones (0.5), Swanlinbar (0.5), Pettigo (0), Muff (0.5), Emyvale (3), Omeath (1), Bundoran (7), Lifford (0.5), Ardee (24), Sligo (28), Manorhamilton (9), Drumshanbo (17), Ballyconnell (10).
} 
Table 7. Accounting for urban population change along the border

\begin{tabular}{lrrrr}
\hline & $1901-26$ & $1926-61$ & $1961-81$ & $1981-2001$ \\
\hline Pop & -0.00 & & & \\
Border & $(-0.68)$ & & & \\
& -8.88 & -10.89 & -21.06 & 2.14 \\
North & $(-1.18)$ & $(-0.90)$ & $(-1.78)$ & $0.21)$ \\
& 6.59 & 0.03 & 18.34 & 27.46 \\
East & $0.85)$ & $(0.00)$ & $(1.49)$ & $(2.62)$ \\
& 2.25 & -9.35 & 2.73 & -8.92 \\
$\mathrm{~N}$ & $(0.29)$ & $(-0.70)$ & $(0.21)$ & $(-0.82)$ \\
$\mathrm{R}^{2}$ & & & & \\
Prob $>\mathrm{F}$ & 0.078 & 0.030 & 0.119 & 0.169 \\
& 0.615 & 0.761 & 0.170 & 0.063 \\
\hline
\end{tabular}

Note: t-statistics in brackets

Table 8. Accounting for urban population change along the border

\begin{tabular}{lrrrr}
\hline & $1901-26$ & \multicolumn{1}{c}{$1926-61$} & \multicolumn{1}{c}{$1961-81$} & $1981-2001$ \\
\hline Miles & & & & \\
North & $0.31(1.03)$ & $2.19(3.59)$ & $1.02(1.47)$ & $0.13(0.23)$ \\
East & $7.05(0.99)$ & $-5.24(-0.48)$ & $15.12(1.20)$ & $27.21(2.57)$ \\
& $2.36(0.31)$ & $-16.02(-1.37)$ & $1.48(0.11)$ & $-9.48(-0.86)$ \\
$\mathrm{N}$ & 42 & 42 & 43 & 43 \\
$\mathrm{R}^{2}$ & 0.051 & 0.260 & 0.098 & 0.169 \\
Prob >F & 0.573 & 0.009 & 0.255 & 0.063 \\
\hline
\end{tabular}

Note: t-statistics in brackets

Border and Miles are intended to measure any border effect. The periods examined are 1901-1926, 1926-61, 1961-81, and 1981-2001/2. For much of the last two periods-between the early 1970 s and mid-1990s-several traditional cross-border routes were unusable.

The outcome is described in tables 7 and 8 . Neither Popgr(t-1) nor Pop(t-1) account for much of the variation in urban population change. The coefficients on North are usually positive, while those on East show no consistent pattern. Most important, there are signs (albeit weak in the statistical sense) of a negative border effect between 1926 and 1981. In other words, up to the 1970s location close to the border seems to have caused slower town growth. The coefficient of -21.06 on Border in 1961-81 implies that predicted population growth of urban centres located on or near the border was twenty-two percentage points less than that of towns located a distance from the border. Similarly, the coefficient of 2.24 on Miles in 1926-61 means that predicted town growth rose by $2.19 \%$ per mile distance from the border. In sum, this result is consistent with the results for county-level data and suggests 
that partition did indeed inflict a cost on villages and towns located near the border until 1981. Whether other, less awkwardly located towns gained what the border towns lost during these decades is another matter. However, for the most recent period analysed-1981-2001/2-there is no evidence of a "border effect" in this sense. This is perhaps the most significant result in tables 11 and 12.

\section{CONCLUSION}

Almost 170 years ago a group of gentlemen appointed to inquire into the viability of an Irish railway network devoted considerable ingenuity to documenting and charting passenger and merchandise flows within and between different parts of Ireland. In their appraisal of a rail line that would link Dublin and Belfast via Navan and Armagh, they found that it:

would cross and intersect the stream of traffic flowing towards the coast and would, therefore, be of very little service in facilitating and promoting the carrying trade of this part of the country. It is on the conveyance of passengers that this line of Railway must rest its chief claim of support as a work of public utility (Railway Commissioners, 1837-38: 15).

Data assembled by the constabulary on passengers carried by mail coach and private coaching companies confirmed the presence of a latent demand for rail travel from commuters and other travellers. However, the Railway Commissioners reiterated their scepticism regarding the Coast Line, taking in what might today be deemed a Belfast-Dublin economic corridor, as follows:

We have to observe, that it [the Coast Line] may be considered altogether in the light of a speculation which has no reference to the internal commercial traffic of the country, but as one which will afford a desirable facility for passenger intercourse between the important commercial towns which it is intended to connect (Railway Commissioners, 1837-38: 44).

Much has changed since the 1830s, but in the 1990s and the 2000s the Railway Commissioners' question about the potential for north-south trade has become topical again. We began with the tongue-in-cheek title "Did (and does) the border Matter?" Our answer is that it did, but less than popular perceptions imply.

History and economic analysis suggest two important points. First, north-south trade on the island of Ireland has always been less than East-West trade with "the mainland". The same holds for human migration. Emigration has long been a more important phenomenon in Ireland than internal migration, and recently immigration has assumed even greater significance. Second-and despite the first point-the volume of merchandise trade between the two Irelands is higher than a standard gravity model invoking data on other flows cross-border flows would predict. No doubt, it would be possible to increase the volume of trade between, say, Dublin and Belfast at the expense of that between, say, Cork and Dublin or Derry and Belfast. But would such trade diversion be warranted by economic criteria? More fruitful might be stimulus to trade between the two Irelands that was not at the expense of 
existing flows, but our results have not revealed any deficiency in the levels of existing flows relative to what it would be reasonable to expect between the two regions in the absence of a border. 27

Although modest projects that increase trust, co-operation, and competition between Northern Ireland and Republic of Ireland businessmen have their political and economic rationale, the best way to ensure growth in north-south trade is the continued growth of the two economies. The upsurge in north-south migration during the "Celtic tiger" boom shows that economic growth matters greatly for migration too.

We end with a cautionary note. Our analysis has moved fairly freely between comparisons of north-south trade and migration with comparable flows between other regions, on the one hand, and an attempt to identify the effect of partition through before/after comparisons. We have found contradictory evidence. On the one hand, the trade flows have been and remain larger than would be predicted from a convention trade model. On the other hand, movement of people between the north and the south is smaller than might be expected and there is some evidence that partition reduced it even further. Finally, we have evidence that partition adversely affected the growth of Republic of Ireland counties and both Northern Ireland and Republic of Ireland towns located close to the border. However, relative to the total population of the island, these effects are small.

\section{REFERENCES}

Boyle, G, T McCarthy and J Walsh (1999) "Regional income differential and the issue of regional equalization in Ireland", Journal of the Statistical and Social Inquiry Society of Ireland 28 (1): 157-96

Crafts, NFR (1995) "The golden age of economic growth in post-war Europe: why did Northern Ireland miss out?", Irish economic and social history. 22: 5-25

Curtis, L (1994) "All along the watchtowers", New internationalist, issue 255

Darcy, M and T Dickson, eds. (1995) Border crossings: developing Ireland's island economy. Dublin: Gill and Macmillan

Fetter, FW (1955) The Irish pound, 1797-1826. London: Allen and Unwin.

Fitzgerald, J, TP Quinn, BJ Whelan and J Williams (1988) An analysis of cross-border shopping. Dublin: Economic and Social Research Institute [ESRI General Research Series no. 137]

Fitzsimmons, E, V Hogan and JP Neary (1999) "Explaining the volume of north-south trade in Ireland: a gravity model approach", Economic and social review 30 (4): 381 401

\footnotetext{
27 The notion of a Dublin-Belfast economic corridor was first mooted by the CBI (NI) and IBEC in 1994. Recently, it has spawned a controversial project to "scope" a "twin city region" encompassing Newry and Dundalk. The new "mini-metropolis" is envisaged as playing a "pivotal" role on the corridor.
} 
Forum for Peace and Reconciliation (1995) The social and economic consequences of peace and economic reconstruction. Dublin: Stationery Office [Consultancy Studies no. 1]

Geary, RC, and JG Hughes (1970a) "Migration between Northern Ireland and the Republic of Ireland", appendix to Walsh, 37-50

Geary, RC, and JG Hughes (1970b) Internal migration in Ireland. Dublin: Economic and Social Research Institute [ESRI Paper no. 54]

Gibson, N (1959) Partition today: a northern viewpoint. Dublin: Tuairim

Hand, GJ, ed. (1969) Report of the Boundary Commission 1925. Shannon: Irish University Press

Honohan, P and BM Walsh (2002) "Catching up with the leaders: the Irish hare", Brookings papers on economic activity 2002 (1): 1-57

Isles, KS, and N Cuthbert (1957) An economic survey of Northern Ireland. Belfast: HMSO

Johnson, DS (1974) "The economic history of Ireland between the wars", Irish economic and social history 1: 49-61

Logue, P, ed. (1999) The border: personal reflections from Ireland North and South. Dublin: Oak Tree Press

Maddison, A (2001) The world economy: a millennial perspective. Paris: OECD

New Ireland Forum (1984) The economic consequences of the division of Ireland since 1920. Dublin: Stationery Office

Norton, D (1986) "Smuggling under the Common Agricultural Policy: Northern Ireland and the Republic of Ireland", Journal of Common Market studies 24 (4): 297-312

Railway Commissioners (1837-38) First Report of the Commissioners Appointed to Inquire into the Manner in which Railway Communications Can be Most Advantageously Promoted in Ireland. British Parliamentary Papers, vol. 35 [75]

Redding, S, and DM Sturm (2005) The costs of remoteness: evidence from German division and reunification. London: Centre for Economic Policy Research [CEPR Working Paper No. 5015]

Robb, HM (1995) "The border region: a case study", pp. pp. 133-143 in Darcy and Dickson, 1995

Scott, R, and M O'Reilly (1992) Exports of Northern Ireland manufacturing companies. Belfast: NIERC

Smyth, A (1995) "Transport: a hard road ahead", pp. 165-85 in Darcy and Dickson, 1995

Simpson, J (1995) "Fiscal realities: the degree of difference", pp. 85-95 in Darcy and Dickson, 1995

Thom, R and B Walsh (2002) "The effect of a currency union on trade: lessons from the Irish experience", European economic review 46, 1111-23

Walsh, BM (1970) Religion and demographic behaviour in Ireland. Dublin: ESRI [General Research Series: Paper No. 55]

Walsh, BM (2000) "Urbanization and the regional distribution of population in Post-Famine Ireland", Journal of European economic history 29 (1): 109-30 
Walsh, J (1995) "Economic geography: how Ireland's wealth is dispersed", pp. 53-66 in Darcy and Dickson, 1995 